\title{
Effects of dietary probiotic and synbiotic supplementation on broiler growth performance and intestinal histomorphology
}

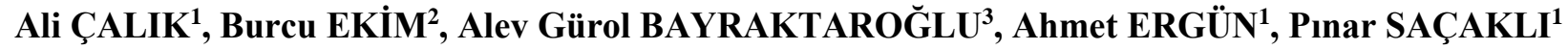 \\ ${ }^{1}$ Ankara University, Faculty of Veterinary Medicine, Department of Animal Nutrition \& Nutritional Diseases; ${ }^{2}$ Gazi University, Life \\ Sciences Research and Application Center; ${ }^{3}$ Ankara University, Faculty of Veterinary Medicine, Department of Histology and \\ Embryology, Ankara, Turkey.
}

Summary: The effects of Paenibacillus xylanexedens, alone or in combination with inulin and lactulose were evaluated on growth performance and intestinal histomorphology of male broilers. A total of 168 one-day-old male broiler chickens were randomly allocated to 4 experimental groups as follows: $\mathrm{C}$, basal diet (control; without supplementation); $\mathrm{P}, 1 \times 10^{9} \mathrm{cfu} / \mathrm{kg}$-feed $P$. xylanexedens; $\mathrm{IN}, 1 \times 10^{9} \mathrm{cfu} / \mathrm{kg}$-feed $P$. xylanexedens and $1 \%$ inulin; LAC, $1 \times 10^{9} \mathrm{cfu} / \mathrm{kg}$-feed $P$. xylanexedens and $0.5 \%$ lactulose. Addition of $P$. xylanexedens and synbiotics significantly increased broiler body weight gain $(\mathrm{P}<0.001)$ and feed conversion ratio $(\mathrm{P}=0.023)$ from 1 to 21 day of age. Moreover, a significant increase in body weight gain was observed when birds were fed with synbiotic supplemented diets during the overall experimental period $(\mathrm{P}=0.013)$. The addition of probiotic and synbiotics increased $(\mathrm{P}=0.047)$ villus height in ileum on day 42 . Our results indicate that $P$. xylanexedens can be used as a probiotic feed additive in broiler diets and can improve broiler performance and intestinal histomorphology.

Keywords: Broiler, intestinal histomorphology, Paenibacillus xylanexedens, performance, probiotic.

\section{Broyler rasyonlarında probiyotik ve sinbiyotik kullanılmasının broyler performans ve bağırsak histomorfolojisi üzerine etkisi}

Özet: Paenibacillus xylanexedens'in tek başına veya inulin veya laktuloz ile birlikte kullanılmasının erkek broylerlerin büyüme performansı ve bağırsak histomorfolojisi üzerine olan etkisi incelendi. Toplamda 168 adet günlük erkek civciv dört deneme grubuna ayrild1: C, bazal rasyon (kontrol); P, $1 \times 10^{9} \mathrm{cfu} / \mathrm{kg}$-yem P. xylanexedens; IN, $1 \times 10^{9} \mathrm{cfu} / \mathrm{kg}-\mathrm{yem} P$. xylanexedens ve $\% 1$ inulin; LAC, $1 \times 10^{9} \mathrm{cfu} / \mathrm{kg}$-yem $P$. xylanexedens ve $\% 0.5$ laktuloz. $P$. xylanexedens ve sinbiyotik ilavesinin $1-21$. günlerde broyler canlı ağırlık $\operatorname{artışını~}(P<0.001)$ ve yemden yararlanma oranını $(\mathrm{P}=0.023)$ önemli düzeyde arttırdığı sonucuna varıldı. Tüm araştırma periyodu dikkate alındığında sinbiyotik ilavesinin canlı ağırlık artışını önemli ölçüde ( $\mathrm{P}=0.013)$ etkilediği görüldü. Araştırmanın 42. gününde probiyotik ve sinbiyotik ilave edilen gruplarda ileum villus yüksekliğinin daha fazla olduğu tespit edildi $(\mathrm{P}=0.047)$. Sonuç olarak, $P$. xylanexedens' in broyler büyüme performansını ve bağırsak histomorfolojisini olumlu yönde etkilediği ve rasyonlarında probiyotik yem katkı maddesi olarak kullanılabileceği görüldü.

Anahtar sözcükler: Bağırsak histomorfolojisi, broyler, Paenibacillus xylanexedens, performans, probiyotik.

\section{Introduction}

Recent international legislations and the increasing concern of domestic consumers over the possibility of antibiotic residues in meat and other animal products have put restrictions on the usage of growth-promoting antibiotics and the availability of antibiotics for the treatment of bacterial infections (21). Ban on the prophylactic use of in-feed antibiotics has encouraged the researchers to search for new and safer alternatives $(3,23)$. In this sense, supplementation of probiotic microorganisms and prebiotic oligosaccharides as an alternative to growth-promoting antibiotics has received increasing interest due to their promising beneficial effects on the broiler performance and intestinal health (28).
Probiotics influence the host organisms' health by maintaining the normal intestinal microbiota, preventing the growth of pathogenic microorganisms, promoting digestion and intake of feed, and inducing the immune system $(24,27)$. Dietary probiotic supplementation has remarkable effects on broiler performance $(16,28,29,30)$, gastro-intestinal mucosa integrity $(6,35)$, composition of the gut microflora $(16,28,37)$, and intestinal immunity (8). Spore forming probiotic bacteria's, such as Bacillus species, has received much more attention than their nonspore-forming counterparts and this particular advantage making them suitable for use as feed supplements in broiler diets $(12,20)$. Paenibacillus is a genus of facultative anaerobic, endospore-forming bacteria, which 
previously distinguished from the other Bacillus groups by comparative 16S rRNA sequence analysis (4).

Synbiotics are defined as combination of probiotics and prebiotics that beneficially affect the host by improving the survival and implantation of newly added strains in the intestine by activating the metabolism of health-promoting bacteria and/or selectively stimulating their growth (19). Synbiotics encourage the growth of the probiotic organism by providing the specific substrate to the probiotic organism for its fermentation (17). Beneficial effects of synbiotics, when compared with probiotics alone, on broiler growth performance, intestinal microflora population, cecal volatile fatty acid concentration and intestinal histomorphological parameters have been reported previously $(6,28)$.

To the best of our knowledge, dietary probiotics and synbiotics influence broiler growth performance and intestinal morphology by selectively stimulating the growth of health-promoting bacteria. However, until now, there has been no information on the effects of $P$. xylanexedens on broiler intestinal health parameters. Based on the previously reported favorable effects of probiotics and synbiotics, the current study was designed to evaluate the effect of $P$. xylanexedens and prebiotic combinations on broiler growth performance and intestinal histomorphology during different periods of production.

\section{Materials and Methods}

Birds and management: A total of 168 one-day-old male broiler chickens (Ross 308), with an average body weight $(\mathrm{BW})$ of $41.12 \pm 0.55 \mathrm{~g}$, were obtained from a commercial hatchery (Beypiliç, Bolu, Turkey). Birds were weighed and randomly allocated to 4 experimental groups with 7 replicate pens $(90 \times 80 \mathrm{~cm})$ containing 6 birds each. Birds were housed in an environmentally controlled room for 42 days. The ambient temperature was thermostatically controlled and gradually decreased from $32-35^{\circ} \mathrm{C}$ on the first day to $22^{\circ} \mathrm{C}$ at 3 weeks of age; the temperature was maintained at $22^{\circ} \mathrm{C}$ thereafter. All experimental procedures were approved by Ankara University, Ethical Committee for Experimental Research on Animals (2013-3-12).

The starter, grower, and finisher diets were based on maize-soybean meal and were offered to the birds from 1 14, 15-35, and 36-42 days of age, respectively (Table 1). All diets were formulated to meet or exceed NRC (32) nutrient recommendations. Each pen was equipped with manual plastic feeders and automatic nipple drinkers. Water and experimental diets (in mash form) were provided ad libitum. Dietary treatments were as follows: $\mathrm{C}$, basal diet (control; without supplementation); $\mathrm{P}, 1 \times 10^{9}$ cfu/kg-feed $P$. xylanexedens; IN, $1 \times 10^{9}$ cfu/kg-feed $P$. xylanexedens and $1 \%$ inulin (Beneo, Orafti IPS, Oreye, Belgium); LAC, $1 \times 10^{9} \mathrm{cfu} / \mathrm{kg}$-feed $P$. xylanexedens and $0.5 \%$ lactulose (Duphalac, Abbott Biologicals B.V. Olst, Netherland). Approximately $7.5 \mathrm{~mL} / \mathrm{kg}$ feed lactulose syrup equivalent to $0.5 \%$ lactulose.

Table 1. Composition of basal diet.

Tablo 1. Bazal rasyonun komposizyonu.

\begin{tabular}{|c|c|c|c|}
\hline Item & $\begin{array}{c}\text { Starter } \\
0 \text { to } 14 \mathrm{~d}\end{array}$ & $\begin{array}{c}\text { Grower } \\
15 \text { to } 35 \mathrm{~d}\end{array}$ & $\begin{array}{c}\text { Finisher } \\
36 \text { to } 42 \mathrm{~d}\end{array}$ \\
\hline \multicolumn{4}{|l|}{ Ingredient, \% } \\
\hline Corn & 39.98 & 47.05 & 45.00 \\
\hline Soybean meal, (CP 47\%) & 30.00 & 24.00 & 24.65 \\
\hline Soybean (Full fat) & 13.00 & 13.00 & 8.50 \\
\hline Wheat & 10.00 & 8.00 & 13.30 \\
\hline Vegetable oil & 2.50 & 3.90 & 5.00 \\
\hline Dicalcium phosphate & 2.25 & 2.00 & 1.85 \\
\hline Limestone & 0.86 & 0.80 & 0.77 \\
\hline Dl-Methionine (98\%) & 0.40 & 0.31 & 0.18 \\
\hline L-Lysine-HCl (78\%) & 0.26 & 0.19 & 0.00 \\
\hline L-Threonine & 0.15 & 0.15 & 0.15 \\
\hline Salt & 0.35 & 0.35 & 0.35 \\
\hline Mineral premix ${ }^{1}$ & 0.10 & 0.10 & 0.10 \\
\hline Vitamin premix ${ }^{2}$ & 0.10 & 0.10 & 0.10 \\
\hline Anticoccidial & 0.05 & 0.05 & 0.05 \\
\hline Total & 100.00 & 100.00 & 100.00 \\
\hline \multicolumn{4}{|c|}{ Chemical composition, calculated } \\
\hline $\mathrm{CP}, \%$ & 23.00 & 20.60 & 19.40 \\
\hline $\mathrm{ME}, \mathrm{kcal} / \mathrm{kg}$ & 3,012 & 3,176 & 3,227 \\
\hline Calcium, $\%$ & 1.00 & 0.90 & 0.85 \\
\hline Available phosphorus, $\%$ & 0.50 & 0.45 & 0.42 \\
\hline Methionine + cysteine, $\%$ & 1.10 & 0.95 & 0.80 \\
\hline Lysine, \% & 1.44 & 1.24 & 1.01 \\
\hline Threonine, $\%$ & 0.99 & 0.91 & 0.86 \\
\hline \multicolumn{4}{|l|}{ Analyzed composition } \\
\hline $\mathrm{CP}, \%$ & 23.12 & 20.65 & 19.50 \\
\hline $\mathrm{ME}, \mathrm{kcal} / \mathrm{kg}$ & 3,008 & 3,180 & 3,223 \\
\hline $\mathrm{Ca}, \%$ & 1.03 & 1.00 & 0.90 \\
\hline Total P, \% & 0.77 & 0.67 & 0.63 \\
\hline
\end{tabular}

${ }^{1}$ Provided per kilogram of complete diet: vitamin A, 12,000 IU; vitamin D3, 2,500 IU; vitamin E, $40 \mathrm{IU}$; vitamin $\mathrm{K} 3,5 \mathrm{mg}$; thiamin, $2.5 \mathrm{mg}$; riboflavin, $6 \mathrm{mg}$; pyridoxine, $5 \mathrm{mg}$; pantothenic acid, $15 \mathrm{mg}$; niacin, $25 \mathrm{mg}$; folic acid, $1 \mathrm{mg}$; biotin, $50 \mu \mathrm{g}$; vitamin B12, $20 \mu \mathrm{g}$.

${ }^{2}$ Provided per kilogram of complete diet: $\mathrm{Cu}, 5 \mathrm{mg}$; $\mathrm{I}, 1 \mathrm{mg}$, Co, $200 \mu \mathrm{g}$; Se, $150 \mu \mathrm{g}$; Fe, 60 mg; Zn, 60 mg; Mn, 80 mg.

${ }^{1}$ Rasyonun her kg' 1 da: vitamin A, 12,000 IU; vitamin D3, 2,500 IU; vitamin E, $40 \mathrm{IU}$; vitamin K3, $5 \mathrm{mg}$; tiamin, $2.5 \mathrm{mg}$; riboflavin, $6 \mathrm{mg}$; piridoksin, $5 \mathrm{mg}$; pantotenik asit, $15 \mathrm{mg}$; niasin, $25 \mathrm{mg}$; folik asit $1 \mathrm{mg}$; biyotin, $50 \mu \mathrm{g}$; vitamin B12, 20 $\mu \mathrm{g}$.

2 Rasyonun her kg'ında: Cu, 5 mg; I, 1 mg, Co, $200 \mu$ g; Se, 150 $\mu \mathrm{g}$; Fe, $60 \mathrm{mg}$; Zn, $60 \mathrm{mg}$; Mn, $80 \mathrm{mg}$. 
Probiotic strain: Paenibacillus xylanexedens strain was isolated from chyme samples of cattles and were collected within sterile tubes. Isolation procedure was adapted from Barbosa et al. (9) The chime samples were suspended in 1:1 phosphate-buffered saline (PBS) solution and spore forming isolates were then selected by ethanol treatment. For ethanol treatment $50 \%$ (v/v) ethanol was added to suspension and incubated at room temperature for one hour. Then 10 -fold serial dilutions up to $10^{-5}$ were made and plated on LB agar. Colonies with distinct morphologies were picked and purified by streaking on LB agar plates. Cultures were incubated at $37^{\circ} \mathrm{C}$ for colony formation and then isolates stored at $80^{\circ} \mathrm{C}$ in $30 \%$ glycerol.

Further identification of the isolate was carried out by $16 \mathrm{~S}$ rRNA sequencing method. In 16S rRNA gene sequencing, approximately 1400 bp was analyzed by Bioedit software and compared with BLAST data from National Center for Biotechnology.

After isolation, resistance to simulated gastric fluids (13), tolerance to bile salt (13), sporulation efficiency (9), spore formation (9), adhesion and invasion properties (34) were tested and the results were given in Table 2 . Antimicrobial activities (26) of isolate against each representative strain (Escherichia coli, Staphylococcus aureus, Klebsiella pneumoniae, Pseudomonas aeruginosa) were evaluated and the results were presented in Table 3.

Table 2. Characterization of $P$. xylanexedens.

Tablo 2. P. xylanexedens' in özellikleri.

\begin{tabular}{lc}
\hline Paenibacillus xylanexedens & \\
\hline Sporulation efficiency (\%) & 81 \\
Survival in simulated gastric fluid (vegetative & + \\
form) & \\
Survival in bile salt (vegetative form) & + \\
Adhesion (\%) & $\mathbf{2 . 6}$ \\
Invasion (\%) & $\mathbf{0}$ \\
\hline
\end{tabular}

Table 3. Antimicrobial activity of isolate $P$. xylanexedens. Tablo 3. P. xylanexedens izolatlarının antimikrobiyel özellikleri.

\begin{tabular}{|c|c|c|c|c|}
\hline \multirow{2}{*}{ Isolate } & \multicolumn{4}{|c|}{$\begin{array}{l}\text { Pathogenic strains and diameters of } \\
\text { inhibition zones }(\mathrm{cm})\end{array}$} \\
\hline & $\begin{array}{c}S . \\
\text { aureus } \\
\end{array}$ & $\begin{array}{c}P . \\
\text { aeruginosa }\end{array}$ & $\begin{array}{c}E . \\
\text { coli }\end{array}$ & $\begin{array}{c}\text { K. } \\
\text { pneumoniae }\end{array}$ \\
\hline $\begin{array}{l}P . \\
\text { xylanexedens }\end{array}$ & 2 & 2 & 2 & 2 \\
\hline
\end{tabular}

Preparation of Paenibacillus xylanexedens as feed additive: Cultures were grown in $50 \mathrm{~mL} \mathrm{DSM}$ at $37^{\circ} \mathrm{C}$, $250 \mathrm{rpm}$ for $24 \mathrm{~h}$ and centrifuged at $3.000 \mathrm{rpm}$ for $5 \mathrm{~min}$. Harvested spores were then inoculated in DSM and incubated at $37^{\circ} \mathrm{C}$ and $250 \mathrm{rpm}$ for $48 \mathrm{~h}$. After the incubation period, spores were centrifuged at $6.000 \mathrm{rpm}$ for $30 \mathrm{~min}$; spore pellets were washed with $20 \mathrm{~mL}$ sterile distilled water and re-suspended in $5 \mathrm{~mL}$ sterile water. Spores of the isolate were then mixed with $10 \%$ skim milk for further lyophilization. Lyophilized cultured were then mixed with a composition of $1 \times 10^{9}$ viable spores (cfu) of Paenibacillus xylanexedens (approximately $0.6 \%$ of net weight) as active substance and with calcium carbonate (approximately 99\% of net weight product) and corn flour (approximately $0.4 \%$ of net weight product) as carriers according to the product specifications of a commercial feed additive.

Growth performance: All chicks were weighed individually and feed intake (FI) was recorded at weekly intervals. Body weight gain (BWG), FI and feed conversion ratio (FCR) were subsequently calculated based on the performance values.

Sampling procedures: At 21 and 42 days of age one bird from each replicate was selected according to the average body weight (BW) of each treatment group. Birds were slaughtered by exsanguination and the intestinal tract was removed immediately. The tissue samples for histomorphological analysis were taken from the jejunum and ileum. To ensure the uniformity of samples, approximately $2 \mathrm{~cm}$ length of the mucosal segments of jejunum and ileum was excised as follows: $8 \mathrm{~cm}$ proximal to Meckel's diverticulum (jejunum), and $8 \mathrm{~cm}$ proximal to the ileo-cecal junction (ileum), respectively.

Histomorphologic measurements: Tissue samples were fixed in $10 \%$ neutral buffered formaline for $24 \mathrm{~h}$ and washed with tap water subsequently dehydrated in graded ethanol solutions, cleared with xylol and embedded in paraffin, respectively. Intestinal segments were sectioned at the thickness of $5 \mu \mathrm{m}$ with microtome. Cross sections were prepared and stained with Mallory's triple stain modified by Crossman in order to determine the intestinal morphometry (15). Villus height was measured from the top of the villus to crypt mouth and crypt depth was defined as distance between basements of the crypt-tocrypt mouth. Histological sections were examined under light microscope (Leica DM 2500, Leica Microsystems $\mathrm{GmbH}$, Wetzlar, Germany) and photographed with Leica DFC450 (Leica Microsystems, Heerbrug, Germany) digital microscope camera. The images were evaluated using ImageJ software (Image J, US National Institutes of Health, Bethesda, MD, USA).

Statistical analysis: Data were analyzed as a completely randomized block design with 4 dietary treatments and 7 replicates using the ANOVA procedure of the SPSS version 14.01 (SPSS Inc., Chicago, IL, USA). Significant differences among treatment groups were tested by Duncan's multiple range tests. Statistical differences were considered significant at $P<0.05$. 
Table 4. Effects of dietary P. xylanexedens and synbiotic supplementations on broiler performance ${ }^{1}$ Tablo 4. Rasyonlara P. xylanexedens ve sinbiyotik ilavesinin broiler performansı üzerine etkisi.

\begin{tabular}{|c|c|c|c|c|c|c|}
\hline \multirow[b]{2}{*}{ Item $^{3}$} & \multicolumn{4}{|c|}{ Dietary treatment ${ }^{2}$} & \multicolumn{2}{|c|}{ Statistics } \\
\hline & $\mathrm{C}$ & $\mathrm{P}$ & IN & LAC & SEM & $P$-value \\
\hline \multicolumn{7}{|l|}{$\overline{\mathrm{BW}, \mathrm{g}}$} \\
\hline 14 & 325.38 & 324.90 & 352.76 & 334.28 & 4.38 & 0.076 \\
\hline 21 & $648.10^{\mathrm{c}}$ & $700.03^{b}$ & $748.34^{\mathrm{a}}$ & $741.00^{\mathrm{ab}}$ & 10.47 & 0.000 \\
\hline 42 & $2594.71^{\mathrm{b}}$ & $2683.43^{\mathrm{ab}}$ & $2791.71^{\mathrm{a}}$ & $2804.43^{\mathrm{a}}$ & 27.65 & 0.013 \\
\hline \multicolumn{7}{|l|}{ BWG, g } \\
\hline $1-14$ & 284.26 & 283.90 & 311.48 & 293.22 & 4.36 & 0.078 \\
\hline $1-21$ & $606.98^{c}$ & $659.03^{\mathrm{b}}$ & $707.06^{\mathrm{a}}$ & $699.93^{\mathrm{ab}}$ & 10.45 & 0.000 \\
\hline $1-42$ & $2553.59^{b}$ & $2642.43^{\mathrm{ab}}$ & $2750.43^{a}$ & $2763.36^{\mathrm{a}}$ & 27.63 & 0.013 \\
\hline \multicolumn{7}{|l|}{ FI, g } \\
\hline $1-14$ & 406.86 & 398.33 & 432.97 & 409.72 & 5.77 & 0.176 \\
\hline $1-21$ & 952.35 & 942.41 & 997.65 & 997.40 & 11.19 & 0.161 \\
\hline $1-42$ & 4342.81 & 4325.99 & 4381.98 & 4520.80 & 35.50 & 0.201 \\
\hline \multicolumn{7}{|l|}{ FCR } \\
\hline $1-14$ & 1.43 & 1.41 & 1.40 & 1.40 & 0.01 & 0.862 \\
\hline $1-21$ & $1.57^{\mathrm{a}}$ & $1.43^{\mathrm{b}}$ & $1.41^{\mathrm{b}}$ & $1.42^{\mathrm{b}}$ & 0.02 & 0.023 \\
\hline $1-42$ & $1.70^{\mathrm{a}}$ & $1.64^{\mathrm{ab}}$ & $1.60^{\mathrm{b}}$ & $1.64^{\mathrm{ab}}$ & 0.01 & 0.048 \\
\hline Mortality, \% & 2.38 & 0 & 2.38 & 2.38 & - & 0.797 \\
\hline
\end{tabular}

${ }^{\mathrm{a}-\mathrm{c}}$ Means with different superscripts in the same row are significantly different $(P<0.05)$.

${ }^{1}$ Data represent mean values of 7 replicates per treatment.

${ }^{2} \mathrm{C}$ : basal diet (control; without supplementation); P: $1 \times 10^{9} \mathrm{cfu} / \mathrm{kg}$ feed $P$. xylanexedens; $\mathrm{IN}: 1 \times 10^{9} \mathrm{cfu} / \mathrm{kg}$ feed $P$. xylanexedens and $1 \%$ inulin; LAC: $1 \times 10^{9} \mathrm{cfu} / \mathrm{kg}$ feed $P$. xylanexedens and $0.5 \%$ lactulose.

${ }^{3}$ BW: body weight; BWG: body weight gain; FI: feed intake; FCR: feed conversion ratio.

${ }^{\mathrm{a}-\mathrm{c}}$ Aynı satırda farklı harf taşıyan ortalama değerler arasındaki farklılıklar istatistiksel olarak önemlidir $(P<0.05)$.

${ }^{1}$ Değerler her bir gruptan seçilen 7 broylerin ortalamasını göstermektedir.

${ }^{2}$ C: bazal rasyon (kontrol; ilave katk1 yok); P: $1 \times 10^{9} \mathrm{cfu} / \mathrm{kg}$ yem P. xylanexedens; IN: $1 \times 10^{9} \mathrm{cfu} / \mathrm{kg}$ yem P. xylanexedens ve $\% 1$ inulin; LAC: $1 \times 10^{9} \mathrm{cfu} / \mathrm{kg}$ yem $P$. xylanexedens ve \%0.5 laktuloz.

${ }^{3}$ BW: canlı ağırlık; BWG: canlı ağılık artışı; FI: yem tüketimi; FCR: yemden yararlanma oranı.

Table 5. Effects of dietary P. xylanexedens and synbiotic supplementations on histomorphological parameters of the jejunum and ileum ${ }^{1}$

Tablo 5. Rasyonlara $P$. xylanexedens ve sinbiyotik ilavesinin jejunum ve ileum histomorfolojisi üzerine etkisi.

\begin{tabular}{|c|c|c|c|c|c|c|}
\hline \multirow[b]{2}{*}{ Item } & \multicolumn{4}{|c|}{ Dietary treatment $^{2}$} & \multicolumn{2}{|c|}{ Statistics } \\
\hline & $\mathrm{C}$ & $\mathrm{P}$ & IN & LAC & SEM & $P$-value \\
\hline \multicolumn{7}{|l|}{ Jejunum } \\
\hline Villus height $(\mu \mathrm{m})$ & 1061.00 & 1034.36 & 1032.79 & 1081.79 & 30.42 & 0.939 \\
\hline Crypt depth $(\mu \mathrm{m})$ & 184.50 & 187.43 & 171.79 & 195.64 & 4.41 & 0.296 \\
\hline VH:CD ratio ${ }^{3}$ & 5.81 & 5.54 & 6.00 & 5.65 & 0.17 & 0.817 \\
\hline \multicolumn{7}{|l|}{ d 42} \\
\hline Villus height $(\mu \mathrm{m})$ & 1446.40 & 1540.33 & 1486.33 & 1444.30 & 30.48 & 0.677 \\
\hline Crypt depth $(\mu \mathrm{m})$ & 194.60 & 209.58 & 215.83 & 196.20 & 4.30 & 0.235 \\
\hline VH:CD ratio & 7.47 & 7.44 & 6.90 & 7.37 & 0.17 & 0.630 \\
\hline \multicolumn{7}{|l|}{ Ileum } \\
\hline \multicolumn{7}{|l|}{$\mathrm{d} 21$} \\
\hline Villus height $(\mu \mathrm{m})$ & $617.71^{\mathrm{ab}}$ & $569.50^{\mathrm{b}}$ & $523.36^{\mathrm{b}}$ & $735.86^{\mathrm{a}}$ & 23.00 & 0.003 \\
\hline Crypt depth $(\mu \mathrm{m})$ & $174.00^{\mathrm{ab}}$ & $163.43^{\mathrm{ab}}$ & $148.00^{\mathrm{b}}$ & $186.50^{\mathrm{a}}$ & 5.18 & 0.048 \\
\hline $\mathrm{VH}: \mathrm{CD}$ ratio & 3.59 & 3.51 & 3.60 & 4.01 & 0.12 & 0.496 \\
\hline \multicolumn{7}{|l|}{ d 42} \\
\hline Villus height $(\mu \mathrm{m})$ & $1019.60^{\mathrm{b}}$ & $1240.36^{\mathrm{a}}$ & $1225.60^{\mathrm{a}}$ & $1231.33^{\mathrm{a}}$ & 32.53 & 0.047 \\
\hline Crypt depth $(\mu \mathrm{m})$ & 187.00 & 190.50 & 179.70 & 165.50 & 4.03 & 0.100 \\
\hline VH:CD ratio & $5.46^{\mathrm{b}}$ & $6.58^{\mathrm{ab}}$ & $6.86^{\mathrm{a}}$ & $7.53^{\mathrm{a}}$ & 0.24 & 0.021 \\
\hline
\end{tabular}

${ }^{\mathrm{a}, \mathrm{b}}$ Means with different superscripts in the same row are significantly different $(P<0.05)$.

${ }^{1}$ Data represent mean values of 7 replicates per treatment.

${ }^{2} \mathrm{C}$ : basal diet (control; without supplementation); P: $1 \times 10^{9} \mathrm{cfu} / \mathrm{kg}$ feed $P$. xylanexedens; $\mathrm{IN}: 1 \times 10^{9} \mathrm{cfu} / \mathrm{kg}$ feed P. xylanexedens and $1 \%$ inulin; LAC: $1 \times 10^{9} \mathrm{cfu} / \mathrm{kg}$ feed $P$. xylanexedens and $0.5 \%$ lactulose.

${ }^{3}$ Villus height to crypt depth ratio.

a,b Aynı satırda farklı harf taşıyan ortalama değerler arasındaki farklılıklar istatistiksel olarak önemlidir $(P<0.05)$.

${ }^{1}$ Değerler her bir gruptan seçilen 7 broylerin ortalamasını göstermektedir.

${ }^{2} \mathrm{C}$ : bazal rasyon (kontrol; ilave katk1 yok); P: $1 \times 10^{9} \mathrm{cfu} / \mathrm{kg}$ yem P. xylanexedens; IN: $1 \times 10^{9} \mathrm{cfu} / \mathrm{kg}$ yem P. xylanexedens ve $\% 1$ inulin; LAC: $1 \times 10^{9} \mathrm{cfu} / \mathrm{kg}$ yem $P$. xylanexedens ve \%0.5 laktuloz.

${ }^{3}$ Villus yüksekliğinin kript derinliğine oranı. 


\section{Results}

Growth performance: The effect of dietary addition of $P$. xylanexedens and synbiotics on BW, BWG, FI, and FCR are shown in Table 4. Dietary treatments did not affect broiler performance in starter period (1-14 d); however, the addition of $P$. xylanexedens and synbiotics significantly increased $(P<0.001)$ broiler BW, BWG and FCR $(P=0.023)$ from 1 to 21 day of age. Moreover, a significant increase in BW $(P=0.013)$ and BWG $(P=$ 0.013 ) were observed when birds fed with synbioticsupplemented diets during the overall experimental period. However, FCR value was lower $(P=0.048)$ for the birds fed with $P$. xylanexedens and inulin supplemented diet from 1 to 42 day of age. Feed intake was not significantly different among all dietary treatment groups from 1 to 14,1 to 21 and 1 to 42 day of age. In addition, no significant mortality rate was observed during the entire experimental period.

Morphological measurement of the jejunum and the ileum: Morphological measurements of the jejunum and the ileum are shown in Table 5. Dietary treatments had no significant effect on villus height, crypt depth and villus height:crypt depth (VH:CD) ratio of the jejunum on day 21 and 42. However, ileum villus height $(P=0.003)$ and crypt depth $(P=0.048)$ were significantly increased for the birds fed with $P$. xylanexedens and lactulose supplemented diets on day 21 . There were no significant differences among the control and treatment groups regarding the ileum $\mathrm{VH}: \mathrm{CD}$ ratio on day 21 . Moreover, ileum villus height was significantly higher $(P=0.047)$ for the bird fed with probiotic and synbiotic supplemented diets in comparison to control. However, VH:CD ratio was consistently higher $(P=0.021)$ for the birds fed with synbiotic supplemented diets on day 42 .

\section{Discussion and Conclusion}

Bacillus species are known to produce several extracellular enzymes including $\alpha$-amylases and cellulose, which increase nutrient digestibility and absorption. In addition, they stimulate growth and proliferation of beneficial facultative anaerobic bacteria, such as Lactobacilli, by creating an anaerobic environment within the gut, which can decrease pathogenic bacteria colonization and improve intestinal integrity $(1,22)$. Similar to Bacillus species, $P$. xylanexedens utilizes several nutrients including D-cellulose, D-fructose, Dgalactose, $\alpha$-D-glucose, lactose, lactulose, maltose (31). Among the beneficial microorganisms, Lactobacillus and Bacillus strains receive much more attention than other probiotic strains in the broiler nutrition. However, so far, there are no reported studies evaluating the effect of $P$. xylanexedens, as a probiotic feed additive, on the broiler growth performance. Previous meta-analysis results have showed that the BWG and FCR were improved in birds that received probiotics in compare to the basal diet without additives (10). Studies with inulin and lactulose also showed pronounced effect on broiler performance by selectively stimulating the beneficial microorganisms (11, 14, 33). The current study indicated that the addition of $P$. xylanexedens alone or in combination with inulin or lactulose significantly increased BWG and FCR of broilers during the first 21 day of age. In agreement with our results, dietary inclusion of Bacillus spp. improved the growth performance of broilers $(1,22,25)$. However, inulin and lactulose supplemented diets were much more effective on broiler performance then those fed basal diet at the end of the experiment. Contrary to our findings, Mookiah et al. (28) have reported that improvements made by synbiotics were not significantly different from those made by probiotic or prebiotic alone at day 42 . According to our results $P$. xylanexedens and prebiotic (especially inulin) combinations showed synergistic effect on broiler overall growth performance. This result is in accordance with the findings of Awad et al. (6) and Ghasemi et al. (18), who found a significant improvement in the broiler performance with the use of synbiotics in broiler diets. It seems that $P$. xylanexedens, as a new promising sporeforming probiotic, may be more efficient on growth performance on broilers when combined with inulin or lactulose. Improved performance of the birds could be related to the beneficial effects of synbiotics on the intestinal microflora and intestinal integrity.

It is widely accepted that the intestinal microbiota and its metabolic activity have significant effects on the broiler health and the performance. In addition there is a growing interest to use of different probiotics to improve intestinal integrity and functionality by selectively altering the intestinal microflora (7). The morphological changes in the small intestine, such as increasing villus height, width, and $\mathrm{VH}: \mathrm{CD}$ ratio might have beneficial effects on bird's performance. These changes enhance the absorptive surface area, which is important when alternative growth stimulators are applied. However, shorter villus is associated with the presence of toxins (5) and deeper crypts can be regarded as a higher demand for new epithelial intestinal tissue (38). In the present study, ileal villus height was increased by dietary $P$. xylanexedens and synbiotics addition on day 42 . However, villus height to crypt depth ratio of ileum was greater for synbiotic supplemented groups. Our results are consistent with Sen et al. (36) who reported increased villus height of ileum in birds fed with Bacillus subtilis LS 1-2 supplemented diets. In addition, dietary inclusion of Bacillus subtilis increased ileum villus height under thermoneutral and heat stress conditions (2). Moreover, dietary inclusion of several probiotics such as, Enterococcus faecium (35), Lactobacillus salivarius and Lactobacillus reuteri (7), improved broiler intestinal integrity. As reported by the 
previous studies $(7,36)$ greater villus height and VH:CD ratio may be related to the ability of $P$. xylanexedens to create a more favorable intestinal microbial environment. We propose that addition of $P$. xylanexedens with inulin and lactulose much more effective on intestinal structure in male broilers.

In conclusion, $P$. xylanexedens, alone or in combination with inulin and lactulose, exerts beneficial effects on broiler performance and intestinal morphology. Further researches are needed to clarify the effect of between $P$. xylanexedens on intestinal microbiota and bacterial metabolites.

\section{Acknowledgements}

The authors would like to thank Beypiliç AŞ and Artısan Gida for material supply.

\section{References}

1. Ahmed ST, Islam M, Mun HS, et al. (2014): Effects of Bacillus amyloliquefaciens as a probiotic strain on growth performance, cecal microflora, and fecal noxious gas emissions of broiler chickens. Poult Sci, 93, 1963-1971.

2. Al-Fataftah AR, Abdelqader A (2014): Effects of dietary Bacillus subtilis on heat-stressed broilers performance, intestinal morphology and microflora composition. Anim Feed Sci Tech, 198, 279-285.

3. Alzueta C, Rodriguez ML, Ortiz LT, et al. (2010): Effects of inulin on growth performance, nutrient digestibility and metabolisable energy in broiler chickens. Br Poult Sci, 51, 393-398.

4. Ash C, Priest FG, Collins MD (1993): Molecular identification of rRNA group 3 bacilli (Ash, Farrow, Wallbanks and Collins) using a PCR probe test. Proposal for the creation of a new genus Paenibacillus. A van Leeuw, 64, 253-260.

5. Awad WA, Bohm J, Razzazi-Fazeli E, et al. (2006): Effect of addition of a probiotic microorganism to broiler diets contaminated with deoxynivalenol on performance and histological alterations of intestinal villi of broiler chickens. Poult Sci, 85, 974-979.

6. Awad WA, Ghareeb K, Abdel-Raheem S, et al. (2009): Effects of dietary inclusion of probiotic and synbiotic on growth performance, organ weights, and intestinal histomorphology of broiler chickens. Poult Sci, 88, 49-56.

7. Awad WA, Ghareeb K, Bohm J (2010): Effect of addition of a probiotic micro-organism to broiler diet on intestinal mucosal architecture and electrophysiological parameters. J Anim Physiol Anim Nutr (Berl), 94, 486-494.

8. Bai SP, Wu AM, Ding XM, et al. (2013): Effects of probiotic-supplemented diets on growth performance and intestinal immune characteristics of broiler chickens. Poult Sci, 92, 663-670.

9. Barbosa TM, Serra CR, La Ragione RM, et al. (2005): Screening for bacillus isolates in the broiler gastrointestinal tract. Appl Environ Microbiol, 71, 968-978.

10. Blajman JE, Frizzo LS, Zbrun MV, et al. (2014): Probiotics and broiler growth performance: A metaanalysis of randomised controlled trials. Br Poult Sci, 55, 483-494.
11. Calik A, Ergun A (2015): Effect of lactulose supplementation on growth performance, intestinal histomorphology, cecal microbial population, and shortchain fatty acid composition of broiler chickens. Poult Sci, 94, 2173-2182.

12. Cartman ST, La Ragione RM, Woodward MJ (2008): Bacillus subtilis spores germinate in the chicken gastrointestinal tract. Appl Environ Microbiol,74, 52545258.

13. Chavarri M, Maranon I, Ares R, et al. (2010): Microencapsulation of a probiotic and prebiotic in alginate-chitosan capsules improves survival in simulated gastro-intestinal conditions. Int J Food Microbiol, 142, 185189.

14. Cho JH, Kim IH (2014): Effects of lactulose supplementation on performance, blood profiles, excreta microbial shedding of Lactobacillus and Escherichia coli, relative organ weight and excreta noxious gas contents in broilers. J Anim Physiol Anim Nutr (Berl), 98, 424-430.

15. Culling CFA, Allison RT, Bar WT (1985): Cellular Pathology Technique, London: Butterworth and Co. Ltd.

16. Deniz G, Orman A, Cetinkaya F, et al. (2011): Effects of probiotic (Bacillus subtilis DSM 17299) supplementation on the caecal microflora and performance in broiler chickens. Rev Med Vet, 11, 538-545.

17. Farnworth ER (2001): Probiotics and prebiotics. In: Wildman REC, editor. Handbook of Nutraceuticals and Functional Foods. Boca Raton, USA: CRC Press; 2001. pp. 407-422.

18. Ghasemi HA, Kasani N, Taherpour K (2014): Effects of black cumin seed (Nigella sativa L.), a probiotic, a prebiotic and a synbiotic on growth performance, immune response and blood characteristics of male broilers. Livest Sci, 164, 128-134.

19. Gibson GR, Roberfroid MB (1995): Dietary modulation of the human colonic microbiota: Introducing the concept of prebiotics. J Nutr, 125, 1401-1412.

20. Hong HA, Duc le H, Cutting SM (2005): The use of bacterial spore formers as probiotics. FEMS Microbiol Rev, 29, 813-835.

21. Huff GR, Huff WE, Rath NC, et al. (2006): Limited treatment with beta-1,3/1,6-glucan improves production values of broiler chickens challenged with Escherichia coli. Poult Sci, 85, 613-618.

22. Jeong JS, Kim IH (2014): Effect of Bacillus subtilis C-3102 spores as a probiotic feed supplement on growth performance, noxious gas emission, and intestinal microflora in broilers. Poult Sci, 93, 3097-3103.

23. Kim GB, Seo YM, Kim CH, et al. (2011): Effect of dietary prebiotic supplementation on the performance, intestinal microflora, and immune response of broilers. Poult Sci, 90, 75-82.

24. Kim KM, Kim MJ, Kim DH, et al. (2009): Characterization of Bacillus polyfermenticus KJS-2 as a probiotic. J Microbiol Biotechn, 19, 1013-1018.

25. Knarreborg A, Brockmann E, Høybye K, et al. (2008): Bacillus subtilis (DSM17299) modulates the ileal microbial communities and improves growth performance in broilers. Int J Probiotics Prebiotics, 3, 83-86.

26. Lertcanawanichakul M, Sawangnop S (2011): A comparison of two methods used for measuring the 
antagonistic activity of Bacillus species. Walailak J Sci Tech, 5, 161-171.

27. Lutful Kabir SM (2009): The role of probiotics in the poultry industry. Int J Mol Sci, 10, 3531-3546.

28. Mookiah S, Sieo CC, Ramasamy K, et al. (2014): Effects of dietary prebiotics, probiotic and synbiotics on performance, caecal bacterial populations and caecal fermentation concentrations of broiler chickens. J Sci Food Agric, 94, 341-348.

29. Mountzouris KC, Tsirtsikos P, Kalamara E, et al. (2007): Evaluation of the efficacy of a probiotic containing Lactobacillus, Bifidobacterium, Enterococcus, and Pediococcus strains in promoting broiler performance and modulating cecal microflora composition and metabolic activities. Poult Sci, 86, 309-317.

30. Mountzouris KC, Tsitrsikos P, Palamidi I, et al. (2010): Effects of probiotic inclusion levels in broiler nutrition on growth performance, nutrient digestibility, plasma immunoglobulins, and cecal microflora composition. Poult Sci, 89, 58-67.

31. Nelson DM, Glawe AJ, Labeda DP, et al. (2009): Paenibacillus tundrae sp. nov. and Paenibacillus xylanexedens sp. nov., psychrotolerant, xylan-degrading bacteria from Alaskan tundra. Int J Syst Evol Micr, 59, 1708-1714.

32. NRC (1994): Nutrient Requirements of Poultry. Washington, DC: Natl. Acad. Press.

33. Rebole A, Ortiz LT, Rodriguez ML, et al. (2010): Effects of inulin and enzyme complex, individually or in combination, on growth performance, intestinal microflora, cecal fermentation characteristics, and jejunal histomorphology in broiler chickens fed a wheat- and barley-based diet. Poult Sci, 89, 276-286.
34. Rowan NJ, Deans K, Anderson JG, et al. (2001): Putative virulence factor expression by clinical and food isolates of Bacillus spp. after growth in reconstituted infant milk formulae. Appl Environ Microbiol, 67, 3873-3881.

35. Samli HE, Senkoylu N, Koc F, et al. (2007): Effects of Enterococcus faecium and dried whey on broiler performance, gut histomorphology and intestinal microbiota. Arch Anim Nutr, 61, 42-49.

36. Sen S, Ingale SL, Kim YW, et al. (2012): Effect of supplementation of Bacillus subtilis LS 1-2 to broiler diets on growth performance, nutrient retention, caecal microbiology and small intestinal morphology. Res Vet Sci, 93, 264-268.

37. Song J, Xiao K, Ke YL, et al. (2014): Effect of a probiotic mixture on intestinal microflora, morphology, and barrier integrity of broilers subjected to heat stress. Poult Sci, 93, 581-588.

38. Yason CV, Summers BA, Schat KA (1987): Pathogenesis of rotavirus infection in various age groups of chickens and turkeys: Pathology. Am J Vet Res, 48, 927-938.

Geliş tarihi:01.02.2016 / Kabul tarihi:15.08.2016

Yazışma adresi:

Prof. Dr. Pınar SAÇAKLI

Ankara Üniversitesi, Veteriner Fakültesi

Hayvan Besleme ve Beslenme Hastalıkları Anabilim Dall,

Dışkapı, Ankara, 06110, Türkiye.

e-mail:Pinar.Sacakli@ankara.edu.tr 